\title{
Late diagnosis iniencephaly with spina bifida
}

\section{Dilek Marangoz Chapman*}

Department of Obstetrics \& Gynaecology, Vezirkopru State Hospital, Samsun, Turkey

Received: 25 August 2015

Revised: 28 August 2015

Accepted: 09 September 2015

\author{
*Correspondence: \\ Dr. Dilek Marangoz Chapman, \\ E-mail: marangozdilek@yahoo.com
}

Copyright: (C) the author(s), publisher and licensee Medip Academy. This is an open-access article distributed under the terms of the Creative Commons Attribution Non-Commercial License, which permits unrestricted non-commercial use, distribution, and reproduction in any medium, provided the original work is properly cited.

\begin{abstract}
Herein a rare case of iniencephaly combined with spina bifida is reported, which was diagnosed late because the G6P5 mother had not attended hospital for first trimester anomaly scans and alpha-fetoprotein measurement. A woman aged 33 years who was 38 weeks pregnant presented for ante-natal follow-up. Her clinical results were normal but abnormalities including polyhydramnios, retroflexion of the head with absence of neck, acrania, and severe growth retardation were observed in the fetus. The infant was delivered through Cesarean section and died shortly after birth. The results of a gross examination revealed acrania, iniencephaly, spina bifida, and an imperforated anus. Iniencephaly is a rare and fatal neural tube defect characterized by extreme retroflexion of the head and severs distortion of the spine. This case report underlines the importance of first trimester anomaly scans and alphafetoprotein measurement.
\end{abstract}

Keywords: Iniencephaly, Spina bifida

\section{INTRODUCTION}

Iniencephaly is a rare (incidence ranging between 0.1 to 10 in 10,000 births) and lethal neural tube defect involving the occiput and inion combined with rachischisis of the cervical and thoracic spine, and characterized by retroflexion of the head and occipital bone malformation. ${ }^{1-3}$ Iniencephaly is more severe than spina bifida but belongs to the same group of neural tube defects. The defects in iniencephaly create extreme retroflexion of the head and distortion of the spine, which results with infants having a 'star gazing' appearance. The neck is absent in most infants with iniencephaly and the skin of the face is directly connected to the chest, and the scalp is directly connected to the back. Iniencephaly is commonly associated with other congenital defects such as anencephaly, cephalocele, cyclopia, lack of a lower jaw bone or cleft lip and palate. Other bodily functions may be also affected, including disorders of the cardiovascular, respiratory, and gastrointestinal systems.
It is not yet clears why the disorder has a higher propensity in females, or if there is a single genetic cause either in iniencephaly or other neural tube defects. The common consensus is that these defects have complex causes, most likely a mix of genetic and environmental factors. ${ }^{4}$ Newborns with iniencephaly have extremely poor prognosis and rarely survive past birth. ${ }^{4}$

\section{CASE REPORT}

A G6P5 pregnant woman aged 33 years was admitted to our clinic for antenatal follow-up. It was her first appointment during her pregnancy, thus she had not undergone a first trimester screening test, alphafetoprotein (AFP) measurements, or an anomaly scan. She was 38 weeks according to her last menstrual period. The patient's blood pressure was $120 / 70 \mathrm{~mm} / \mathrm{Hg}$, body mass index was 24 and blood glucose level was $85 \mathrm{mg} / \mathrm{dL}$. She had no signs of gestational diabetes or preeclampsia and claimed not to have used any medication other than 
anti-anemics during pregnancy. The patient was otherwise healthy. During her sonographic examination we noticed polyhydramnios, retroflexion of the head with absence of the neck, acrania, and severe growth retardation and explained the findings to the parents who were consanguineous first cousins. We performed a Cesarean section because of the transverse presentation of the fetus. A 1450 gr live male fetus was delivered but the baby did not breathe and died within a few minutes. The family refused autopsy or MRI for further investigations and wanted to bury the baby as soon as possible according to religious beliefs. On gross examination, the baby had acrania, iniencephaly, spina bifida, and an imperforated anus. (Figures 1, 2, and 3)

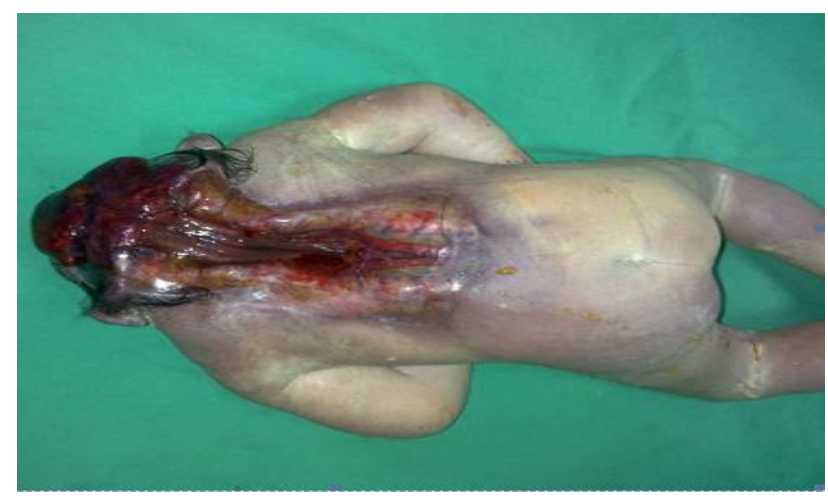

Figure 1: Acrania, spina bifida, iniencephaly.

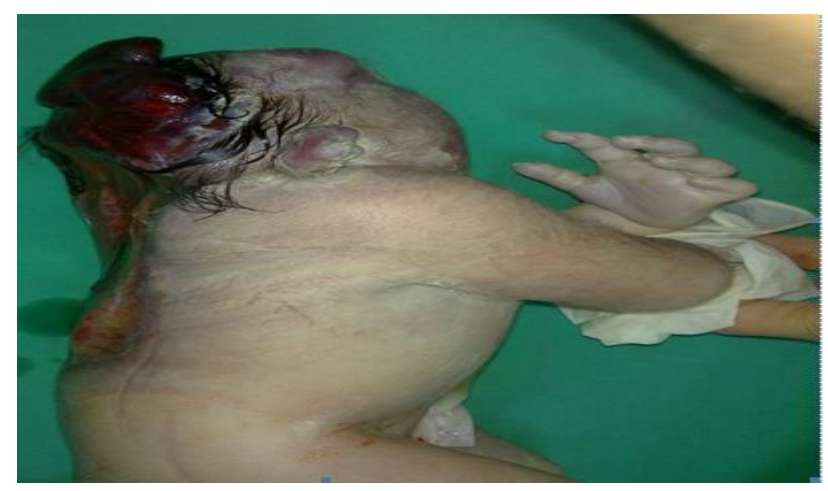

Figure 2: Absence of acrania, neck, iniencephaly.

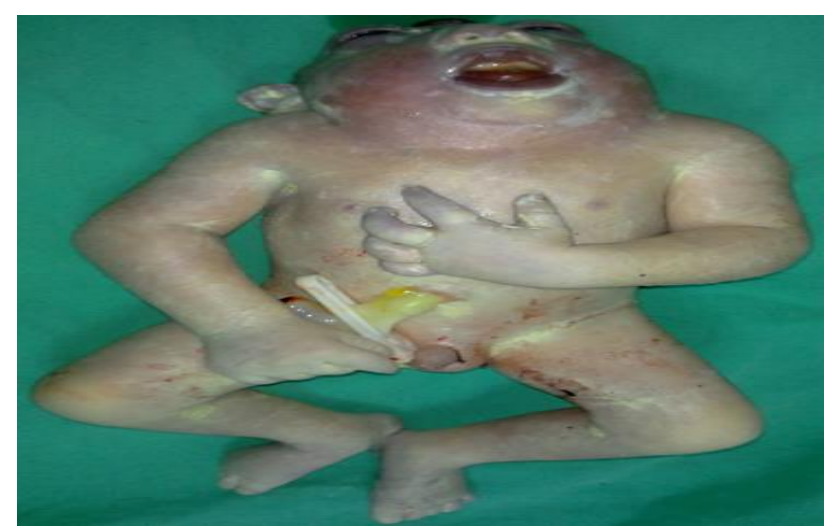

Figure 3: Acrania.

\section{DISCUSSION}

Iniencephaly is an extremely rare birth defect that develops when the neural tube, which develops into the brain and spinal cord, fails to close during fetal development. ${ }^{4}$ The time of onset is likely a little after that of anencephaly. ${ }^{5}$ The two main iniencephaly groups were first described by Lewis: iniencephaly apertus, which has an encephalocele, and iniencephaly clausus, which has a spinal defect but no cephalocele. ${ }^{1}$

The main features of iniencephaly include a variable deficit of the occipital bones that results in an enlarged foramen magnum; partial or total absence of cervical and thoracic vertebrae with irregular fusion of those present, and incomplete closure of the vertebral arches and bodies; marked reduction of the spinal column due to lordosis and hyper-extension of the malformed cervicalthoracic spine; and an upward-turned face with mandibular skin that is directly continuous with that of the chest, owing to the lack of neck.

Iniencephaly can be easily detected in a standard sonographic examination because of the gross alterations of intracranial anatomy, spine, and fetal position. ${ }^{6-10}$

Sonographic diagnosis based on the extreme dorsal flexion of the head, the unusually short and deformed cervical and thoracic spine, and overall fetal shortening. The head retroflexion and spinal disorganization are visible on medial-sagittal scans of the spinal column. Anencephaly or cephaloceles are present in the open forms.

Most prenatally diagnosed cases of iniencephaly present with high AFP and polyhydramnios. The differential diagnosis includes Klippel-Feil syndrome (shortness of the neck associated with fusion of cervical vertebrae), anencephaly, and a cervical myelomeningocele. ${ }^{11}$ Distinguishing between iniencephaly clausus and Klippel-Feil syndrome is challenging and remains the subject of debate with some physicians speculating that Klippel-Feil syndrome may indeed be iniencephaly, albeit in a much milder form. ${ }^{12,13}$

Associated anomalies often include cephalocele, holoprosencephaly, spina bifida, omphalocele, gastrochisis, diaphragmatic hernia or agenesis, pulmonary hypoplasia or hyperplasia, cardiac malformations, renal anomalies, overgrowth of the arms compared with the legs, genu recurvatum, arthrogryposis, clubfoot, and gastrointestinal atresia.,14

Iniencephaly apertus is always fatal shortly after birth and as such there is no standard treatment. Very few cases of long-term survival of very mild iniencephalus clausus have been reported in which the deformity was minimal and by definition, should probably have been classified as Klippel-Feil syndrome. ${ }^{15}$ 
The clinical focus has been based more on prevention using folic acid supplementation. Mothers can minimize the risk of neural tube birth defects by up to $70 \%$ with daily dietary supplements of at least $4 \mathrm{mg}$ folic acid. Medications such as antiepileptic drugs, diuretics, antihistamines, and sulfa drugs have been shown to be associated with an increased risk of neural tube defects and as such these should be avoided during pregnancy. Other risk factors include maternal obesity and diabetes. ${ }^{3}$

This case report underlines the importance of first trimester anomaly scans and alpha-fetoprotein measurement.

\section{ACKNOWLEDGEMENT}

The author would like to thank Mr David F. Chapman for his assistance with language editing.

Funding: No funding sources Conflict of interest: None declared

Ethical approval: Not required

\section{REFERENCES}

1. Lewis HL. Iniencephalus Am J Obstet. 1897;35:1153.

2. Nishimura H, Okamoto N. iniencephaly. In: Vinken PJ, Bruyn GW,eds. Handbook of clinical neurology, vol.30. New York: North-Holland Biomedical Press. 1977:257-68.

3. Pungavkar SA, Sainani NI, Karnik AS et al. "Antenatal diagnosis of iniencephaly: Sonographic and MR correlation: a case report". Korean Journal of Radiology. 2007;8:351-5.

4. David N,John P. Gahan, Dolores P, Gianluigi Pilu. Diagnostic imaging of fetal anomalies. 2003;315-16

5. Gardner WJ. Klippel-Feil syndrome, iniencephalus, anencephalus, hindbrain hernia and minor movements: overdistention of the neural tube. Child Brain. 1979;5;361-9.

6. Morocz I, Szeifert T, Molnar P, et al. Prenatal diagnosis and pathoanatomy of iniencephaly. Clin Neuropathol. 1986;30:81-6.

7. Meizner I, Bar-Ziv J. Prenatal ultrasonic diagnosis of a rare case of iniencephaly apertus. J Clin Ultrasound. 1987;15:200-03.

8. Romero R, Pilu G, Jeanty P, et al. Prenatal diagnosis of congenital anomalies. Norwalk, CT: Appleton \& Lange. 1988:64-7.

9. Sahid S, Sepulveda W, Dezerega V, et al. Iniencephaly: prenatal diagnosis and management. Prenat Diagn. 2000;20:202-05.

10. Shoham Z, Caspi B, Chemke J, et al. Iniencephaly: prenatal ultrasonographic diagnosis- a case report. J Perinat Med. 1988;16:139-43.

11. Gunderson $\mathrm{CH}$, Greenspan $\mathrm{RH}$, Glaser $\mathrm{G}$, et al. The Klippel-Feil syndrome: genetic and clinical reevalualion of cervical fusion. Medicine. 1967;46:491-512.

12. Gilmour JR. The essential identity of Klippel-Feil syndrome and iniencephaly. J Pathol. 1941;53:11731.

13. Sherk HH, Shut L, Chung S. Iniencephalic deformity of the cervical spine with Klippel-Feil anomalies and congenital evaluation of the scapula.

14. Lemire, RJ, Beckwith, B, Shephard TH.Iniencephaly and anencephaly with spinal retroflexion: a comparative study of eight human specimens. Teratology. 1972;6:27-36.

15. Katz VL, Aylsworth AS, Albright SG. Iniencephaly is not uniformly fatal. Prenat Diag. 1989:595-9.

Cite this article as: Chapman DM. Late diagnosis iniencephaly with spina bifida. Int J Reprod Contracept Obstet Gynecol 2015;4:1543-5. 